\title{
Comparison of growth parameters of 40 varieties/clones short rotation coppice willow (Salix)
}

\author{
Attila Bako - Diana Tóthová \\ Slovak University of Agriculture in Nitra, Faculty of European Studies and Regional Development, \\ Department of Sustainable Development, Mariánska 10, 94976 Nitra, Slovak Republic. \\ attila.bako@uniag.sk
}

Keywords: Salix, survival rate, stem numbers per plant, stem height, stem diameter and cluster analysis.

\section{SUMMARY}

The plantation of willow varieties was established in 2009. The 40 different varieties and clones of Salix were planted at a research field in Kolínany (Nitra district). The paper evaluates results from the first growing season in 2009. The survival rate of planted cuttings ranged from $55.56 \%$ to $100.00 \%$ after the first year. The lowest survival rate was reached by Terra Nova variety. The stem numbers per plant ranged from $1.17 \pm 0.37$ to $2.53 \pm 0.98$. The average height of one-year old stem varied from $65.82 \pm 36.60 \mathrm{~cm}$ to $225.58 \pm 68.61 \mathrm{~cm}$. The average stem diameter ranged from $6.90 \pm 2.63 \mathrm{~mm}$ to $14.34 \pm 3.39 \mathrm{~mm}$. There were statistically very significant differences in parameters of stem height stem diameter and stem numbers per plant among studied varieties/clones. The statistic method used was analysis of variance ANOVA. The varieties were then divided into 6 groups according to their similarity in observed parameters after the first growing season by cluster analysis. The best results were reached by varieties/clones classified in the second group. The survival rate, stem diameter and stem height values of these varieties/clones were above average.

\section{INTRODUCTION}

The use of biomass is expected to increase in the future and cellulose plants might became dominant in this process in the second half of the 21 st century (Luckow et al., 2010). One possible means of biomass production is energy plantations of fast-growing trees (short rotation coppice - SRC). In our climatic conditions, mainly varieties of poplars (Populus sp.) and willows (Salix sp.) are used (Weger et al., 2004), which are also grown on agricultural land. SRC should be grown on less productive soils to avoid endangering the food security. These plants can be grown on about 1 million ha of agricultural land according to the division of land resources in Slovakia, which represents $43 \%$ of the arable land area. However, only part of these soils meets plant requirements (VÚPOP, 2010, 2010a). The planting of these trees is also dependant on suitability of varieties for the environmental conditions. The selection of appropriate varieties and clones well adaptable for the environmental conditions is necessary to ensure a sufficient choice for producers of fast-growing plants. This is the task of breeding experiments, where findings of frost resistance, phenological stages, growth, water use efficiency and drought resistance are the most studied. Laboratory experiments are also focused on the physiological effects of heavy metals on willows, where significant genetic differences were shown among varieties in susceptibility to heavy metals (FAO, 2008). The evaluations of willow varieties/clones performances are carrying out for different environmental conditions in which they are directly tested (Tharakan et al., 2001). The purpose of these programs is breeding of suitable varieties/clones and also development of methodologies for intensive farming. The aim of the breeding is also to increase a biomass production, upright growth, increase of leaf rust and insect resistance and tolerance to low temperatures (Larsson, 1998), as the older varieties of willow are susceptible to rust and tend to produce only one dominant shoot (Aylott et al., 2008). The aim of this paper is to evaluate the partial results from the first growing season is 2009 of a three-year testing cycle (20092011) of 40 fast-growing willows varieties and clones by using cluster analysis.

\section{MATERIAL AND METHODS}

\section{Research field}

The research field is located in the cadastral territory of Kolínany in Nitra district, northeast at a distance of about $8 \mathrm{~km}$ from the town of Nitra $\left(48^{\circ} 21^{\prime} 20^{\prime \prime N}, 18^{\circ} 12^{\prime} 23^{\prime \prime} \mathrm{V}\right)$. The very experimental area is located approximately $500 \mathrm{~m}$ west-northwest from a small dam in Kolínany in the alluvium of Bocegaj stream. The territory of the research field is flat with an altitude of $180 \mathrm{~m} \mathrm{n}$. $\mathrm{m}$. The size of the field is approximately 0.5 hectares. The area belongs to warm, very dry, lowland climatic region. The sum of average daily temperatures above $10{ }^{\circ} \mathrm{C}$ is $3000-2800{ }^{\circ} \mathrm{C}$. The number of days with air temperature above $5{ }^{\circ} \mathrm{C}$ is 237 . The average temperature in January is -1 up to $-3{ }^{\circ} \mathrm{C}$; average temperature of the growing season is 15 up to $17{ }^{\circ} \mathrm{C}$. The average annual temperature is $9.9^{\circ} \mathrm{C}$. The soil is Gleyic Fluvisol, medium clay. The soil is free of skeleton with a depth $60 \mathrm{~cm}$ and more (Linkeš et al., 1996). Based on the soil chemical analysis the pH values range from 7.18 to 7.35 and humus content varies from 1.16 to $2.50 \%$. The long-term average annual rainfall (1951-2000) is $547.6 \mathrm{~mm}$. The number of days with snow cover is 37.9 (Špánik, Šiška, 2008). The groundwater level is located at a depth of 1.0 to $2.0 \mathrm{~m}$, depending on the time of the year and position of measurements. 


\section{Studied varieties}

12 varieties and 28 clones were tested in the research trial. 18 individuals were chosen from each variety/clone. The planting material was supplied by Swedish R\&D institution Lantmännen Agroenergi AB and the Swedish Agricultural University in Uppsala. The Table 1. shows a list of the planting material.

List of planting material after breeding origin and number in plantation

\begin{tabular}{lcccc}
\hline $\begin{array}{c}\text { willow varieties } \\
\text { Sweden - 12 }\end{array}$ & $\begin{array}{c}\text { willow clones } \\
\text { Sweden - 14 }\end{array}$ & $\begin{array}{c}\text { willow clones } \\
\text { Sweden - }\end{array}$ & $\begin{array}{c}\text { willow clones } \\
\text { Sweden - 4 }\end{array}$ & $\begin{array}{c}\text { willow clones } \\
\text { England-1 }\end{array}$ \\
\hline 5. Jorunn & 27. SW 990551 & 18. LA 030054 & 1. L 78183 & 17. SW 901290 \\
6. Jorr & 28. SW 990559 & 19. LA 030068 & 2. L 78195 & \\
7. Björn & 29. SW 010230 & 20. LA 030136 & 3. L 81084 & \\
8. Tora & 30. SW 010329 & 21. LA 030275 & 4. L 78021 & \\
9. Inger & 31. SW 010483 & 22. LA 980260 & & \\
10. Klara & 32. SW 010485 & 23. LA 980263 & \\
11. Lisa & 33. SW 010488 & 24. LA 980268 & \\
12. Stina & 34. SW 040027 & 25. LA 990398 & \\
13. Terra Nova & 35. SW 040028 & 26. LA 000231 & \\
14. Loden & 36. SW 040030 & & & \\
15. Gudrun & 37. SW 040110 & & & \\
16. Dimitrios & 38. SW 060114 & & \\
& 39. SW 060119 & & \\
\end{tabular}

\section{Site preparation, establishment and plantation management}

The subsoil ploughing in autumn 2008 preceded the planting of cuttings. The research area was not managed in that year and no herbicides were applied. The planting area was prepared by cultivation systems and individual plots of studied varieties and clones were marked out in spring 2009. Mineral fertilizers were applied at the plantation at rate of $75 \mathrm{~kg} \cdot \mathrm{ha}^{-1}$ of N, $50 \mathrm{~kg} \cdot \mathrm{ha}^{-1}$ of $\mathrm{P}$ and $25 \mathrm{~kg} \cdot \mathrm{ha}^{-1}$ of K. The research field represents an area of $60.00 \times 17.25 \mathrm{~m}$ (Figure 1.).

Figure 1. Spacing of varieties and clones in plantation with detail of distances between plants (cm)

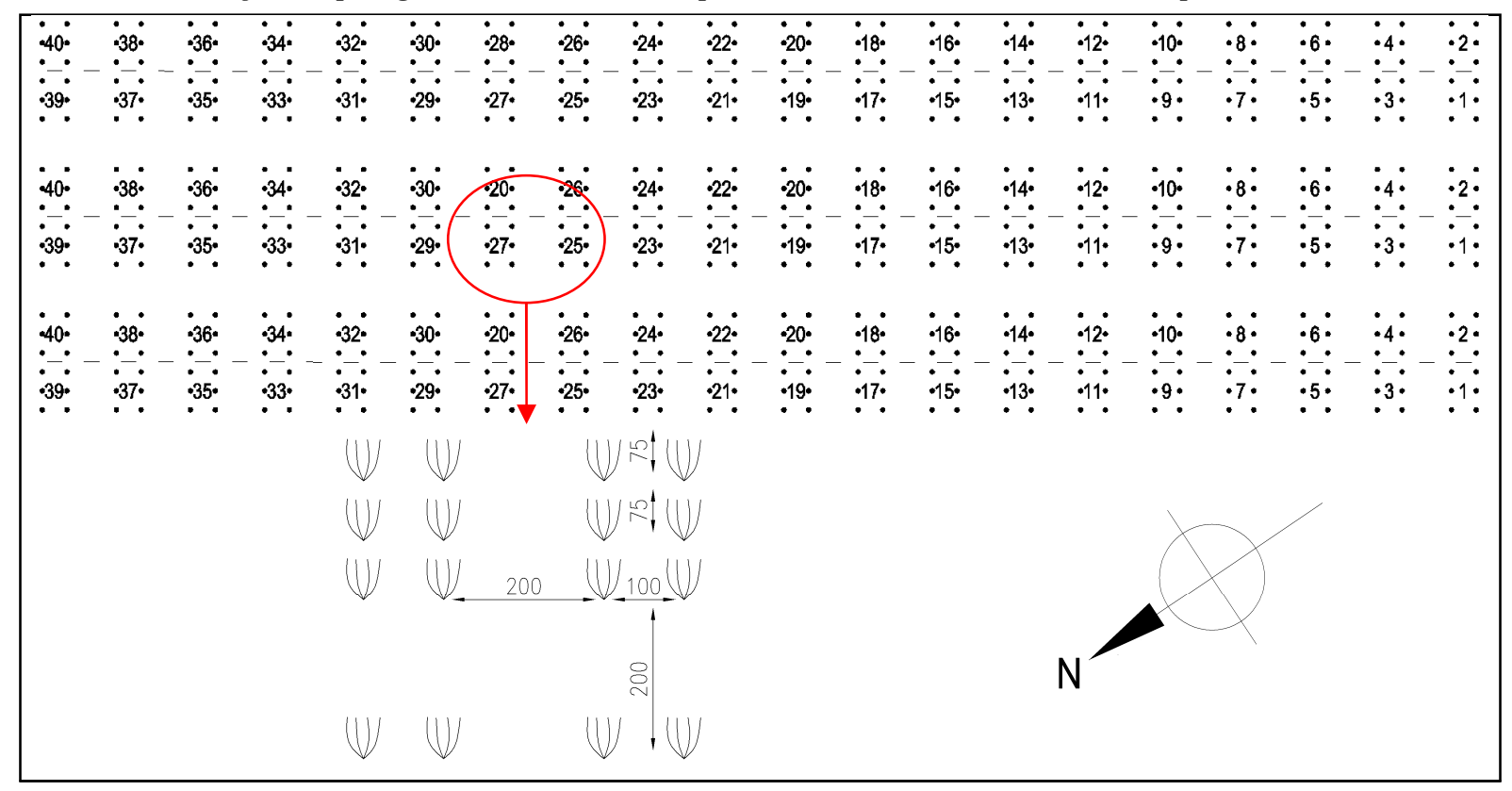

The planting area was established $3 \mathrm{~m}$ apart from the previously established willow plantation with 1-year old shoots (2-year roots). The planting of cuttings was done on $16^{\text {th }}$ of April $2009.20 \mathrm{~cm}$ long dormant cuttings were planted by hand. Cuttings were planted in twin-rows, in three repetitions with the width of $1 \mathrm{~m}$ between the rows, $2 \mathrm{~m}$ between the two twin-rows and $0.75 \mathrm{~m}$ between the individual plants. The planting density of this 
spacing is 8889 cuttings.ha $^{-1}$. The soil lost moisture very quickly due to high air temperature in April. The irrigation of approximately $5 \mathrm{~mm}$ was applied once at the beginning of May. The weed was manually removed by hoeing among the young plants with assistance of cultivator between the twin-rows, totally 4 times during the growing season. The plantation was temporarily fenced for a winter period due to a possible damage by rabbits and game.

\section{Measurements and evaluation}

The number of living plants was counted in January 2010. The survival rate (SR) (\% of rooted cuttings) was determined based on the number of living plants from the total planted cuttings.

The stem numbers per plant $\left(\mathrm{N}_{\mathrm{s}}\right)$, stem heights $\left(\mathrm{h}_{\mathrm{s}}\right)$ and stem diameters $\left(\mathrm{D}_{20}\right)$ were measured in January after the first growing season. The stem height was measured by folding rule and telescopic measuring rod mEssfix $8 \mathrm{~m}$ (Nedo company). The stem diameter was measured $20 \mathrm{~cm}$ above the ground using slide rule. Measured data were analyzed by analysis of variance ANOVA $(\alpha=0.05)$. The aim was to find statistically significant differences in the stem numbers, stem heights and stem diameters among the studied varieties and clones and differences in stem heights and stem diameters depending on the stem numbers.

According to the data gained after the first growing season we grouped the studied varieties and clones into the groups based on similarity of parameters (survival rate, stem numbers per plant, stem heights and stem diameters) in order to better identify groups of willows, with above-average values of these parameters and those below-average. Evaluation was carried out in IBM SPSS Statistics 19, where cluster analysis was used (Average Linkage (Between Groups), Euclidean distance).

\section{RESULTS AND DISCUSSION}

Survival rate of planted cuttings ranged from $55.56 \%$ (variety Terra Nova) to $100 \%$ (16 varieties/clones) at the end of the growing season. In our opinion, the cause of Terra Nova cuttings mortality was particularly genetic characteristics, since variety Loden (No. 14) planted in the same twin-row as the Terra Nova had a $100 \%$ survival rate of planted cuttings. The varieties in adjacent double-rows had a survival rate from 94.44 to $100 \%$. We suppose that variety Terra Nova did not meet the requirements of planting material quality. Dawson (2007) mentions that quality planting material reaches around $90 \%$ of survival rate. Bergkvist et al. (1996) and Kiernan et al. (2003) considered survival rate of more than $80 \%$ as an economic limit of successful establishment.

The stem numbers per plant ranged from $1.17 \pm 0.37$ to $2.53 \pm 0.98$ in average. There were statistically significant differences among varieties and clones (table 2). The average stem height and stem diameter of studied varieties and clones largely decreased with increasing number of stems. Within the parameter of the average height $\left(h_{s}\right)$ of the studied varieties between 1-stem plants and 4-stem plants, we found a difference of $40.15 \mathrm{~cm}$ on average in favor of 1-stem plants, which represents $26.99 \%$ of height of the 1 -stem plant. The differences depending on number of stems were also found in average stem diameter $\left(\mathrm{D}_{20}\right)$. The difference of $2.83 \mathrm{~mm}$ was found between the 1-stem and 4-stem plants which represents $24.14 \%$ of the average stem diameter of 1-stem plant. The minimum stem height of studied varieties and clones ranged from 23 to $99 \mathrm{~cm}$. It should be pointed out that minimum stem heights were not reached by any multistem plant varieties/clones where the dominant shoot oppressed others. In some cases, where the cuttings were probably less rooted, the 1stem plants reached minimum stem heights in comparison with others. Maximum stem height ranged from 111 to $366 \mathrm{~cm}$. The values of stem heights ranged on average from $65.82 \pm 36.60 \mathrm{~cm}$ (No. $23-$ LA 980263$)$ to $225.58 \pm 68.61 \mathrm{~cm}$ (No. 11 - Lisa), while there was not statistically significant difference in the stem numbers per plant between these two varieties. Only two shoots of 16 rooted plants of the variety no. 23 exceeded the height of $100 \mathrm{~cm}$. We found statistically significant differences among the stem heights of studied varieties and clones (table 2). The minimum stem diameter of studied varieties and clones ranged from 2.5 to $7.7 \mathrm{~mm}$. Maximum stem diameter ranged from 11.0 to $28.3 \mathrm{~mm}$. The values of stem diameter ranged on average from $6.90 \pm 2.63$ (No. 23 - LA 980263 ) to $14.34 \pm 3.39$ (No. 11 - Lisa). We found statistically high significant differences among the stem diameters of studied varieties and clones (Table 2.).

Analysis of variance of individual compared parameters

\begin{tabular}{|c|c|c|c|c|}
\hline compared parameter & $\mathrm{F}$ & $\mathrm{P}$ value & F crit. & Significance \\
\hline The number of shoots among varieties/clones & 3.36575503 & $1.45 .10^{-10}$ & 1.41900405 & +++ \\
\hline Stem height depending on the number of shoots & 3.46112070 & 0.01847057 & 2.67769904 & + \\
\hline Stem diameter depending on number of shoots & 5.94924346 & $7.99 .10^{-04}$ & 2.67769904 & +++ \\
\hline
\end{tabular}


The Table 3. shows overall summary of studied parameters $S R, \mathrm{~N}_{\mathrm{s}}, \mathrm{h}_{\mathrm{s}}, \mathrm{D}_{20}$ for each variety and clone.

Table 3

Data of survival rate and average values of stem numbers per plant stem height and stem diameter

\begin{tabular}{|c|c|c|c|c|c|c|c|c|c|}
\hline \multirow{3}{*}{$\frac{\text { no. }}{1}$} & \multirow{3}{*}{$\frac{\text { Variety/Clone }}{\text { L } 78183}$} & \multirow{3}{*}{$\begin{array}{c}\text { Survival rate (SR) } \\
{[\%]} \\
100.00 \%\end{array}$} & \multirow{2}{*}{\multicolumn{2}{|c|}{$\frac{\text { Number of shoots }\left(\mathrm{N}_{\mathrm{s}}\right)}{[-]}$}} & \multirow{2}{*}{\multicolumn{2}{|c|}{$\begin{array}{c}\text { Stem height }\left(\mathrm{h}_{\mathrm{s}}\right) \\
{[\mathrm{cm}]}\end{array}$}} & \multirow{2}{*}{\multicolumn{3}{|c|}{$\frac{\text { Stem diameter }\left(\mathrm{D}_{20}\right)}{[\mathrm{mm}]}$}} \\
\hline & & & & & & & & & \\
\hline & & & 2.22 & \pm 0.53 & 114.63 & $\pm \quad 31.81$ & 9.28 & \pm & 2.81 \\
\hline 2 & L 78195 & $100.00 \%$ & 2.11 & \pm 0.66 & 149.34 & $\pm \quad 40.27$ & 10.30 & \pm & 2.44 \\
\hline 3 & L 81084 & $100.00 \%$ & 2.44 & \pm 0.68 & 179.00 & \pm 33.96 & 12.76 & \pm & 2.80 \\
\hline 4 & L 78021 & $94.44 \%$ & 2.53 & $\pm \quad 0.98$ & 135.23 & $\pm \quad 46.08$ & 9.23 & \pm & 2.49 \\
\hline 5 & Jorunn & $100.00 \%$ & 1.94 & \pm 0.62 & 188.77 & \pm 50.94 & 11.55 & \pm & 2.40 \\
\hline 6 & Jorr & $100.00 \%$ & 2.39 & $\pm \quad 0.83$ & 191.51 & \pm 56.89 & 12.23 & \pm & 3.44 \\
\hline 7 & Björn & $100.00 \%$ & 2.00 & $\pm \quad 0.75$ & 202.75 & $\pm \quad 46.76$ & 12.74 & \pm & 3.05 \\
\hline 8 & Tora & $77.78 \%$ & 2.07 & $\pm \quad 0.80$ & 202.90 & \pm 57.43 & 13.40 & \pm & 3.39 \\
\hline 9 & Inger & $100.00 \%$ & 1.67 & $\pm \quad 0.88$ & 211.53 & \pm 70.27 & 13.33 & \pm & 4.22 \\
\hline 10 & Klara & $100.00 \%$ & 1.56 & $\pm \quad 0.83$ & 193.46 & \pm 70.74 & 12.57 & \pm & 4.13 \\
\hline 11 & Lisa & $100.00 \%$ & 1.44 & $\pm \quad 0.50$ & 225.58 & \pm 68.61 & 14.34 & \pm & 3.39 \\
\hline 12 & Stina & $83.33 \%$ & 1.93 & $\pm \quad 0.85$ & 145.34 & \pm 58.99 & 11.21 & \pm & 3.77 \\
\hline 13 & Terra Nova & $55.56 \%$ & 2.40 & $\pm \quad 1.02$ & 136.42 & \pm 59.35 & 11.42 & \pm & 3.59 \\
\hline 14 & Loden & $100.00 \%$ & 1.50 & $\pm \quad 0.50$ & 157.48 & $\pm \quad 33.79$ & 12.26 & \pm & 2.50 \\
\hline 15 & Gudrun & $94.44 \%$ & 1.71 & $\pm \quad 0.75$ & 105.86 & $\pm \quad 46.01$ & 8.39 & \pm & 2.63 \\
\hline 16 & Dimitrios & $77.78 \%$ & 1.71 & $\pm \quad 0.70$ & 85.29 & \pm 55.13 & 8.74 & \pm & 4.23 \\
\hline 17 & SW 901290 & $94.44 \%$ & 1.76 & $\pm \quad 0.81$ & 111.23 & \pm 40.11 & 7.88 & \pm & 2.06 \\
\hline 18 & LA 030054 & $88.89 \%$ & 2.06 & $\pm \quad 0.75$ & 98.64 & $\pm \quad 45.27$ & 8.28 & \pm & 2.83 \\
\hline 19 & LA 030068 & $100.00 \%$ & 1.78 & \pm 0.63 & 131.41 & $\pm \quad 47.66$ & 8.50 & \pm & 2.09 \\
\hline 20 & LA 030136 & $100.00 \%$ & 1.94 & $\pm \quad 0.62$ & 98.60 & $\pm \quad 44.94$ & 7.72 & \pm & 2.10 \\
\hline 21 & LA 030275 & $100.00 \%$ & 1.72 & $\pm \quad 0.87$ & 70.14 & $\pm \quad 27.91$ & 7.17 & \pm & 1.99 \\
\hline 22 & LA 980260 & $72.22 \%$ & 1.46 & $\pm \quad 0.84$ & 90.42 & \pm 50.51 & 9.78 & \pm & 3.01 \\
\hline 23 & LA 980263 & $88.89 \%$ & 1.75 & $\pm \quad 0.75$ & 65.82 & $\pm \quad 36.60$ & 6.90 & \pm & 2.63 \\
\hline 24 & LA 980268 & $83.33 \%$ & 1.60 & $\pm \quad 0.49$ & 98.46 & $\pm \quad 54.79$ & 9.07 & \pm & 3.53 \\
\hline 25 & LA 990398 & $94.44 \%$ & 2.00 & $\pm \quad 0.77$ & 102.71 & $\pm \quad 44.52$ & 7.97 & \pm & 2.38 \\
\hline 26 & LA 000231 & $94.44 \%$ & 1.88 & $\pm \quad 0.47$ & 123.78 & \pm 64.67 & 9.35 & \pm & 2.86 \\
\hline 27 & SW 990551 & $66.67 \%$ & 1.17 & \pm 0.37 & 79.93 & $\pm \quad 31.45$ & 8.42 & \pm & 2.34 \\
\hline 28 & SW 990559 & $88.89 \%$ & 1.63 & $\pm \quad 0.70$ & 66.96 & $\pm \quad 43.87$ & 7.97 & \pm & 3.97 \\
\hline 29 & SW 010230 & $94.44 \%$ & 1.53 & $\pm \quad 0.61$ & 100.46 & $\pm \quad 35.59$ & 7.73 & \pm & 1.97 \\
\hline 30 & SW 010329 & $83.33 \%$ & 1.53 & $\pm \quad 0.50$ & 111.13 & $\pm \quad 35.15$ & 9.29 & \pm & 2.43 \\
\hline 31 & SW 010483 & $100.00 \%$ & 2.44 & $\pm \quad 0.50$ & 76.55 & 14.83 & 8.52 & \pm & 1.46 \\
\hline 32 & SW 010485 & $94.44 \%$ & 2.53 & $\pm \quad 0.98$ & 105.91 & \pm 54.64 & 9.86 & \pm & 2.74 \\
\hline 33 & SW 010488 & $94.44 \%$ & 1.71 & \pm 0.57 & 103.17 & \pm 53.76 & 9.29 & \pm & 3.00 \\
\hline 34 & SW 040027 & $94.44 \%$ & 1.82 & $\pm \quad 0.71$ & 174.48 & \pm 81.05 & 14.14 & \pm & 4.45 \\
\hline 35 & SW 040028 & $94.44 \%$ & 1.65 & $\pm \quad 0.68$ & 162.00 & \pm 82.41 & 14.07 & \pm & 5.03 \\
\hline 36 & SW 040030 & $100.00 \%$ & 1.94 & $\pm \quad 0.78$ & 137.37 & \pm 78.17 & 12.89 & \pm & 4.12 \\
\hline 37 & SW 040110 & $94.44 \%$ & 1.65 & $\pm \quad 0.59$ & 71.25 & $\pm \quad 22.74$ & 9.45 & \pm & 3.65 \\
\hline 38 & SW 060114 & $100.00 \%$ & 2.39 & $\pm \quad 0.76$ & 93.21 & $\pm \quad 49.40$ & 10.40 & \pm & 2.92 \\
\hline 39 & SW 060119 & $72.22 \%$ & 1.54 & \pm 0.63 & 69.50 & \pm 31.03 & 7.28 & \pm & 2.39 \\
\hline 40 & SW 060120 & $94.44 \%$ & 1.88 & $\pm \quad 0.90$ & 67.03 & $\pm \quad 21.78$ & 7.13 & \pm & 2.09 \\
\hline
\end{tabular}

The result of cluster analysis is the classification of varieties and clones into 6 groups according to their similarity in the measured parameters of stem heights, stem diameters, stem numbers per plant and survival rate (Table 4.). The $1^{\text {st }}$ group includes varieties and clones, which were above-average in stem numbers and survival rate in comparison with other groups (5 varieties). The $2^{\text {nd }}$ group consists of varieties and clones with aboveaverage stem diameters, stem heights and survival rate ( 7 varieties, 5 clones). The $3^{\text {rd }}$ group includes varieties and clones with above-average of stem heights, stem diameters and stem numbers but below-average values of survival rate ( 2 varieties). The $4^{\text {th }}$ group includes the variety Terra Nova, which had the lowest survival rate of all studied varieties and clones (the variety reached above-average values in other parameters). The $5^{\text {th }}$ group 
includes varieties and clones with below-average stem diameter ( 1 variety, 13 clones) and the $6^{\text {th }}$ group includes varieties and clones with below-average values in all measured parameters ( 1 variety, 5 clones). These results represent the first growing season therefore definitive conclusions cannot be made.

Table 4 Groups of varieties and clones based on similarity in studied parameters evaluated by method of average linkage of cluster analysis

\begin{tabular}{|c|c|c|c|c|c|}
\hline $1^{\text {st }}$ group & $2^{\text {nd }}$ group & $3^{\text {rd }}$ group & $4^{\text {th }}$ group & $5^{\text {th }}$ group & $6^{\text {th }}$ group \\
\hline 1. L 78183 & 2. L 78195 & 8. Tora & 13. Terra Nova & 15. Gudrun & 16. Dimitrios \\
\hline 4. L 78021 & 3. L 81084 & 12. Stina & & 17. SW 901290 & 22. LA 980260 \\
\hline 31. SW 010483 & 5. Jorunn & & & 18. LA 030054 & 24. LA 980268 \\
\hline 32. SW 010485 & 6. Jorr & & & 19. LA 030068 & 27. SW 990551 \\
\hline \multirow[t]{10}{*}{ 38. SW 060114} & 7. Björn & & & 20. LA 030136 & 30. SW 010329 \\
\hline & 9. Inger & & & 21. LA 030275 & 39. SW 060119 \\
\hline & 10. Klara & & & 23. LA 980263 & \\
\hline & 11. Lisa & & & 25. LA 990398 & \\
\hline & 14. Loden & & & 26. LA 000231 & \\
\hline & 34. SW 040027 & & & 28. SW 990559 & \\
\hline & 35. SW 040028 & & & 29. SW 010230 & \\
\hline & 36. SW 040030 & & & 33. SW 010488 & \\
\hline & & & & 37. SW 040110 & \\
\hline & & & & 40. SW 060120 & \\
\hline
\end{tabular}

If we compare the reached values of measured parameters in the individual categories with the average value, there are not all varieties and clones in any group, which are above-average in all observed parameters. Despite of this, we can consider the varieties and clones in the 2 nd group as the best based on the observed parameters. Willows show different range of tolerance and growth potential as well as requirements on the environment (Kuzovkina, Volk, 2009). Our results obtained by the method of cluster analysis are mainly based on the ability of adaptation and reproduction of these plants in the given environment and thus the production indicators of the tested varieties and clones also depend on this ability.

The Figure 2. shows dendrogram of average linkage clustering.

\section{Figure 2.: Dendrogram of average linkage clustering among groups}

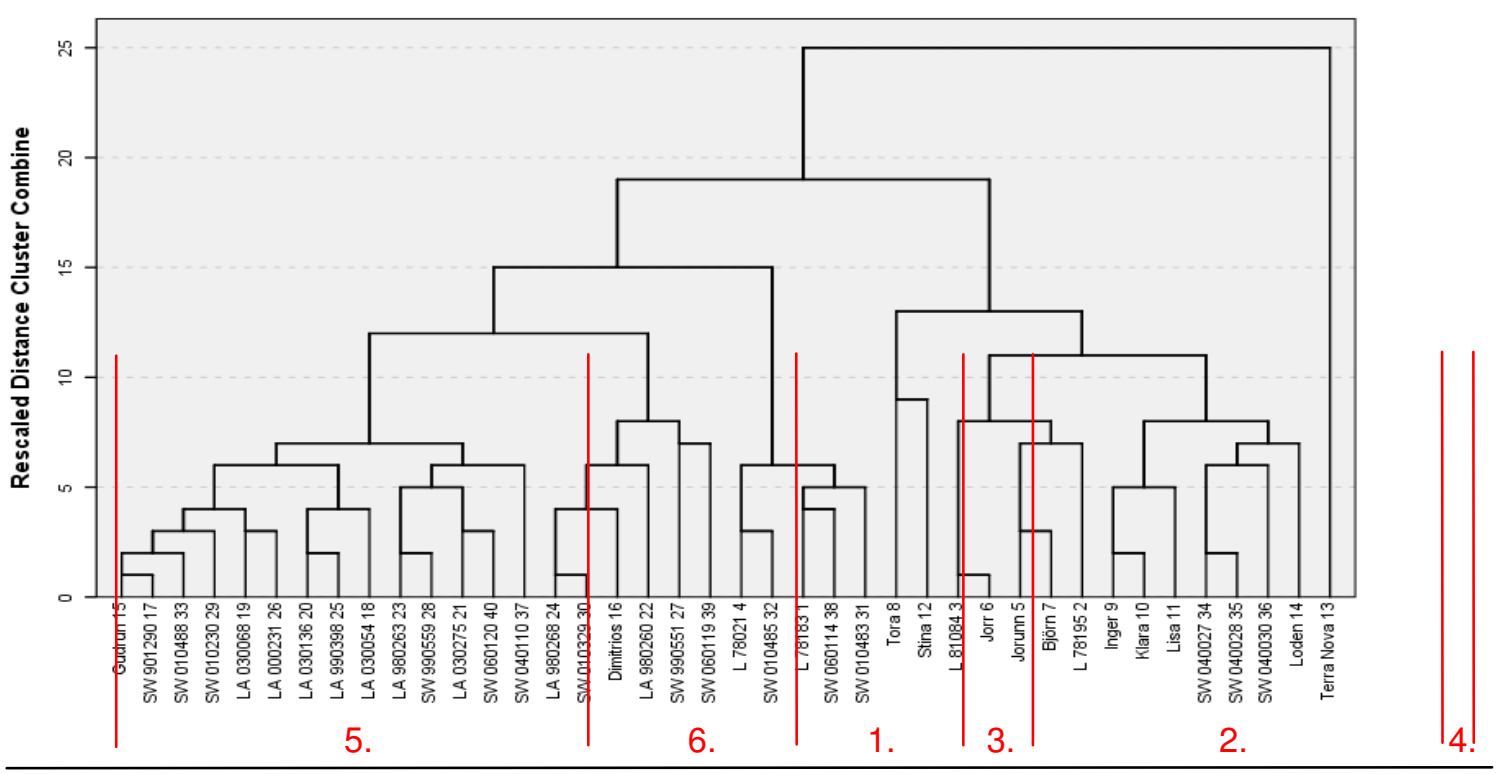

\section{CONCLUSION}

The paper presents partial results of verifying the suitability of 40 fast growing energy willows (Salix) varieties and clones cultivated in conditions of south-west Slovakia during one-year old growing season in 2009. 
We found out that survival rate of planted cuttings varied from 55.56 to $100.00 \%$. The lowest survival rate was reached by the variety Terra Nova with the value of $55.56 \%$. We assume that this variety has worse ability of vegetative reproduction in the given conditions.

The stem numbers per plant ranged from 1 to 4 shoots, rarely 5 . The varietal dependency of shoot production after planting has been statistically confirmed. We also found dependence of the decrease of stem height and stem diameter on the increase of stem numbers. The height of one-year old stems ranged from 23.00 to $366 \mathrm{~cm}$; on average of $65.82 \pm 36.60$ to $225.58 \pm 68.61 \mathrm{~cm}$ at the end of the growing period. Stem diameters were measured $20 \mathrm{~cm}$ above the ground and ranged from 2.5 to $28.3 \mathrm{~mm}$; average stem diameters were from $6.90 \pm 2.63$ to $14.34 \pm 3.39 \mathrm{~mm}$. Parameters of stem height and stem diameter depended on variety/clone which was statistically confirmed.

Results of cluster analysis confirmed the similarity of studied varieties and clones, based on which they were divided into 6 groups. According to the observed parameters of stem numbers per plant, stem heights and stem diameters and survival rate of planted cuttings, the best values were reached by varieties and clones in the second group.

\section{ACKNOWLEDGEMENT}

This work was supported by the Slovak Research and Development Agency under the contract No. APVV0131-07.

\section{REFERENCES}

Aylott, M. J.-Casella, e.-Tubby, I.-Street N. R.-Smith P.-Taylor G. (2008): Yield and spatial supply of bioenergy poplar and willow shortrotation coppice in the UK. New Phytologist, 178. 2. 358-370. Doi: 10.1111/j.1469-8137.2008.02396.x.

Bergkvist, P.-Nordh, N.-Ledin, S.-Olsson, T. (1996): Plant material for short-rotation forestry. LEDIN S. - WILLEBRAND, E. (eds.). Handbook on How to Grow Short Rotation Forests. Swedish Univ. of Agr. Sci.

Dawson, M. (2007): Short Rotation Coppice Willow - Best Practice Guidelines. 50.

http://www.ruralgeneration.com/Boiler\%20Brochures/best\%20practice\%20guide\%281\%29.pdf
FAO. (2008): Poplars, Willows and People's Wellbeing - Synthesis of Country Progress Reports. $\mathrm{ftp} / / / \mathrm{ftp}$.fao.org/docrep/fao/011/k3380e/k3380e.pdf

B.D. Kiernan,-T.A. Volk-P.J. Tharakan-C.A Nowak-S.P. Phillipon-L.P. Abrahamson-E.H. White (2003): Clon-site testing selections for scale-up plantations. Final report. State University of New York, New York. 76. http://www.esf.edu/willow/pdf/reports/2003\%20clonesitefinal.pdf

Kuzovkina, Y. A.-Volk, T. A. (2009): The characterization of willow (Salix L.) varieties for use in ecological engineering applications: Coordination of structure, function and autecology. Ecological Engineering, 35. 8. 1178-1189.

Larsson, S. (1998): Genetic improvement of willow for short-rotation coppice. Biomass and Bioenergy, 15. 1. 23-26. ISSN 0961-9534, DOI: 10.1016/S0961-9534(98)80003-2.

Linkeš, V.-Pestún, V.-Džatko, M. (1996): Príručka pre používanie máp bonitovaných pôdno-ekologických jednotiek. Výskumný ústav pôdnej úrodnosti, Bratislava, 104. http://www.podnemapy.sk/portal/verejnost/bpej/priruckaBPEJ.pdf>. ISBN 80-85361-19-1

Luckow, P-Wise, M.-Dooley, J.-Kim, S. (2010): Biomass Energy for Transport and Electricity: Large scale utilization under low CO2 concentration scenarios. Pacific Northwest National Laboratory, Richland, WA.

Špánik. F-Šiška, B. (2008): Agroklimatické hodnotenie krajiny a základy agroklimatické rajonizácie. SPU, Nitra, 88. ISBN 978-80-5520017-0.

Tharakan, P. J. -Robison, D. J.-Abrahamson, L. P.-Nowak, C. A. (2001): Multivariate approach for integrated evaluation of clonal biomass production potential. Biomass and Bioenergy, 21. 4. 237-247. ISSN 0961-9534. DOI: 10.1016/S0961-9534(01)00038-1.

Vúpop. (2010): Sekundárny pôdny fond. http://www.podnemapy.sk/portal/verejnost/multifunkcne/prim_sek_ost.aspx\#sekundarny

Vúpop. (2010a): Ostaný pôdny fond. http://www.podnemapy.sk/portal/verejnost/multifunkcne/prim_sek_ost.aspx\#ostatny

Weger, J.-Vlasák, P.-Havlíčková, K. (2004): Shrnutí a vývoj situace výmladkových plantáží rychle rostoucích dřevin pro produkci biomasy v ČR a ve Švédsku. Biom.cz. ISSN 1801-2655. http://biom.cz/cz/odborne-clanky/shrnuti-a-vyvoj-situace-vymladkovych-plantazi-rychlerostoucich-drevin-pro-produkci-biomasy-v-cr-a-ve-svedsku 